\title{
Screening the Multi-Element Content of Pleurotus Mushroom Species Using inductively Coupled Plasma Optical Emission Spectrometer (ICP-OES)
}

\author{
Marek Siwulski $^{1}$ - Miroslaw Mleczek ${ }^{2}$ • Piotr Rzymski ${ }^{3}$ - Anna Budka ${ }^{4}$. \\ Agnieszka Jasińska $^{1} \cdot$ Przemyslaw Niedzielski $^{5} \cdot$ Pavel Kalač $^{6}$ • Monika Gąsecka ${ }^{2}$. \\ Sylwia Budzyńska ${ }^{2}$ Patrycja Mikołajczak ${ }^{1}$
}

Received: 3 May 2016 / Accepted: 6 July 2016 / Published online: 16 July 2016

(C) The Author(s) 2016. This article is published with open access at Springerlink.com

\begin{abstract}
Considering the worldwide popularity of cultivated Pleurotus mushrooms as food, analyses of their chemical composition are required to ensure product safety. The aim of this study was to compare the content of 62 elements in fruit bodies of six cultivated species of the genus Pleurotus (five strains of Pleurotus ostreatus, Pleurotus eryngii, Pleurotus djamor, Pleurotus citrinopileatus, Pleurotus florida, and Pleurotus pulmonarius), collected from their producers between 2009 and 2015. Only 31 elements (Al, As, B, $\mathrm{Ca}, \mathrm{Cd}, \mathrm{Cr}, \mathrm{Cu}, \mathrm{Er}, \mathrm{Fe}, \mathrm{In}, \mathrm{K}, \mathrm{Lu}, \mathrm{Mg}, \mathrm{Mn}, \mathrm{Na}, \mathrm{Nd}, \mathrm{P}, \mathrm{Pb}, \mathrm{Pt}$, $\mathrm{Re}, \mathrm{Rh}, \mathrm{Sc}, \mathrm{Se}, \mathrm{Sr}, \mathrm{Te}, \mathrm{Th}, \mathrm{Ti}, \mathrm{Tm}, \mathrm{U}, \mathrm{Zn}$, and $\mathrm{Zr}$ ) were detectable in the tested Pleurotus species in each year of their collection. The obtained results revealed three significantly diverse groups with similar abilities to accumulate 31 elements within 7 years of mushroom production. The species
\end{abstract}

Electronic supplementary material The online version of this article (doi:10.1007/s12161-016-0608-1) contains supplementary material, which is available to authorized users.

Piotr Rzymski

rzymskipiotr@ump.edu.pl

1 Department of Vegetable Crops, Poznan University of Life Sciences, Poznań, Poland

2 Department of Chemistry, Poznan University of Life Sciences, Poznan, Poland

3 Department of Environmental Medicine, Poznan University of Medical Sciences, Poznan, Poland

4 Department of Mathematical and Statistical Methods, Poznan University of Life Sciences, Poznań, Poland

5 Faculty of Chemistry, Adam Mickiewicz University in Poznań, Poznań, Poland

6 Department of Applied Chemistry, Faculty of Agriculture, University of South Bohemia, České Budějovice, Czech Republic and strains were grouped as follows: P. florida and P. pulmonarius (first group); P. ostreatus HK35, P. ostreatus 930, P. eryngii, and $P$. djamor (second group); and P. ostreatus 80, P. ostreatus $\mathrm{H} 195$, P. ostreatus $\mathrm{K} 22$, and P. citrinopileatus (third group). In spite of differences between the tested Pleurotus species and strains, presented in the form of graphical Heatmaps, the intake of these mushrooms was not related with any health risk for consumers.

Keywords Edible mushrooms $\cdot$ Pleurotus $\cdot$ ICP-OES · Elemental analyses

\section{Introduction}

World production of mushrooms has increased nearly 25 -fold over the last 35 years (1978-2012) and the global consumption of both wild and cultivated mushrooms has risen from approximately $1 \mathrm{~kg}$ in 1997 to $4 \mathrm{~kg}$ per capita in 2012 (Royse 2014). Pleurotus species, after Agaricus spp. are the second most cultivated and consumed mushrooms in the world. Between 1997 and 2010, Pleurotus spp. production increased from 876,000 to $6,288,000 \mathrm{t}$ (data exclude production in India) (Chang 1999; Li 2012; USDA 2014; Sanchez and Mata 2012; Royse 2013; Yamanaka 2011). The greatest rise in production was reported in China and accounted for over $85 \%$ of the world's total output in 2010. Approximately one fourth of China's mushroom production in 2010 was constituted by two species, Pleurotus ostreatus and Pleurotus cornucopiae (Li 2012). In Japan, production of Pleurotus spp. almost doubled between 1997 (13,300 t) and 2010 $(39,600$ t) while Pleurotus eryngii experienced the largest gains in production, increasing from $6734 \mathrm{t}$ in 2000 to over 37,000 $\mathrm{t}$ in 2009 (Yamanaka 2011). 
Mushrooms from the genus Pleurotus (higher Basidiomycetes) are widely distributed around the globe with the exception of Antarctica (Zervakis et al. 2001). Under varying climate conditions different ecotypes of Pleurotus mushrooms have become established, among which commercially important ones include the following: P. ostreatus (oyster mushroom), P. eryngii (king oyster mushroom), Pleurotus djamor (pink oyster mushroom), Pleurotus citrinopileatus (golden oyster mushroom), Pleurotus florida (white oyster mushroom), and Pleurotus pulmonarius (Indian Oyster, Phoenix Oyster). However, phylogenetic studies have demonstrated that some of them, e.g., P. ostreatus and P. florida, represent in fact a single species (Gonzalez and Labarere 2000). The abovementioned common names are used in trade. Altogether, Pleurotus spp. makes up almost $27 \%$ of globally produced cultivated mushrooms (Chaubey et al. 2010; Royse 2014). Mushrooms of the genus Pleurotus break down cellulose, lignin, and hemicellulose during mycelium growth on materials of plant origin (Mikiashvili et al. 2004; Naik et al. 2012). Therefore, the most common cultivation substrates for this genus are easily accessible lignocellulose materials (Hassan et al. 2010; Moonmoon et al. 2010).

In Europe, in countries such as France, Italy, the Czech Republic, Slovakia, and Poland, cereal straw and agricultural and forestry wastes are used most often for cultivation of this genus (Akyüz and Yildiz 2008; Kirbag and Akyüz 2008). However, in countries with warmer climates such as Japan, Korea, China, or in South America, mostly rice straw, wood chips mixed with sliced straw, blends of various sawdusts with cotton husks, wheat bran, or soy in various proportions are employed (Qi et al. 2007; Akyüz and Yildiz 2008). The composition of the cultivation substrate greatly affects the growth of mycelium and yield, and to a large extent, determines the chemical composition of fruit bodies.

The fruit bodies of all Pleurotus species are generally characterized by a very good flavor and aroma and possess high nutritional value (particularly as regards to protein, fiber, potassium, calcium, magnesium, and iron content). Due to their low content of lipids and sugars, they are classified as a low-energy food item (Yujie et al. 2007; Bernaś et al. 2006; Kalač 2016). Moreover, they possess therapeutical potential owing to the biological activities of their metabolites (Daba et al. 2008; Dundar et al. 2008).

Mineral composition differs between species of Pleurotus mushrooms ranging from 4 to $10 \%$ of dry matter (Deepalakshmi and Mirunalini 2014). The reported content of macro, micro, and trace elements of several Pleurotus species are presented in Table 1. The most commonly evaluated trace elements in Pleurotus mushrooms are $\mathrm{Hg}$, As, $\mathrm{Cd}$, and $\mathrm{Pb}$. The standard element contents in various edible mushrooms from unpolluted areas, expressed as milligrams per kilogram in dry matter $(\mathrm{dm})$, are as follows: Al 20-150, As $<0.5-5$, Ba 2-4, Cd 1-5, Co $<0.5$, Cr 0.5-5, $\mathrm{Cu} 20-100$, Fe 50-300, Hg <0.5-5, Mn 10-60, Ni 15, Pb $<5, \mathrm{Se}<2, \mathrm{Sb}<0.1$, and Zn 25-200 (Kalač 2010). In general, all wood-decaying species of mushroom are low in $\mathrm{Hg}$ when compared to soil mushrooms. Mushrooms from the genus Pleurotus provide a good illustration of this. In the 1980s, Brunnert and Zadrazil (1983) found very high translocation rates of externally applied $\mathrm{Cd}$ and $\mathrm{Hg}$ in $P$. djamor and P. ostreatus. Recent research by Nnorom et al. $(2012,2013)$ has demonstrated that $P$. ostreatus contains between 0.028 and $0.031 \mathrm{mg} \mathrm{kg}^{-1} \mathrm{dm}$ of $\mathrm{Hg}$ in caps and $0.028-0.0370 \mathrm{mg} \mathrm{kg}^{-1} \mathrm{dm}$ in stipes, whereas Pleurotus tuber-regium contains from 0.024 to $0.048 \mathrm{mg} \mathrm{kg}^{-1} \mathrm{dm}$. The maximum content of $\mathrm{Cd}$ permitted by the European Union regulation in cultivated Agaricus bisporus, P. ostreatus, and Lentinula edodes is $2.0 \mathrm{mg} \mathrm{kg}^{-1} \mathrm{dm}$ (assuming $90 \%$ moisture) (Gucia et al. 2012). The reported $\mathrm{Cd}$ contents of A. bisporus, P. ostreatus, and L. edodes from Hungary showed the content of $\mathrm{Cd}$ in caps to be $0.17 \pm 0.13,0.91 \pm 0.32$, and $0.71 \pm 0.48 \mathrm{mg} \mathrm{kg}^{-1} \mathrm{dm}$, respectively (Vetter et al. 2005); while on sale in Brazil, the content of $\mathrm{Cd}$ ranged between 0.011 and $0.23 \mathrm{mg} \mathrm{kg}^{-1} \mathrm{dm}$ (Maihara et al. 2008). The maximum content of $\mathrm{Pb}$ permitted by the European Union regulation in cultivated A. bisporus, P. ostreatus, and L. edodes is $3.0 \mathrm{mg} \mathrm{kg}^{-1} \mathrm{dm}$ (assuming $90 \%$ moisture) (cited after Gucia et al. 2012). In cultivated species reported by Muñoz et al. (2005), contents of $\mathrm{Pb}$ were below $3.0 \mathrm{mg} \mathrm{kg}^{-1} \mathrm{dm}$ (A. bisporus caps) $0.41 \mathrm{mg} \mathrm{kg}^{-1} \mathrm{dm}$, and P. ostreatus $0.91 \mathrm{mg} \mathrm{kg}^{-1} \mathrm{dm}$-data from Mexico). Pleurotus sajor-caju was reported to accumulate $\mathrm{Pb}$ in the amount of $4.24 \mathrm{mg} \mathrm{kg}^{-1} \mathrm{dm}$ (Chauhan 2013). Studies of cultivated $P$. ostreatus from the European market by Costa-Silva et al. (2011) showed that Se was at $0.10 \pm 0.01$ to $0.26 \pm 0.20 \mathrm{mg} \mathrm{kg}^{-1} \mathrm{dm}$, while the Se content of samples from the USA was $0.2 \mathrm{mg} \mathrm{kg}^{-1} \mathrm{dm}$ (Hong et al. 2011). Cultivated mushrooms A. bisporus, P. ostreatus, P. florida, P. eryngii, and L. edodes contained As in amounts ranging between 0.009 and $0.210 \mathrm{mg} \mathrm{kg}^{-1} \mathrm{dm}$ (Maihara et al. 2008). However, no maximum permitted levels have yet been set for inorganic As and methylmercury, although they are the most toxic species of As and $\mathrm{Hg}$, respectively (Cordeiro et al. 2015). The research of Borovicka et al. (2011) showed that P. pulmonarius collected from unpolluted sites in the Czech Republic contained trace elements such as $\mathrm{U}$ and $\mathrm{Th}$ at levels of 3.25 and $11.4 \mu \mathrm{g} \mathrm{kg}^{-1} \mathrm{dm}$, respectively; $\mathrm{Ag}$ and $\mathrm{Pb}$ at 7.55 and $0.13 \mathrm{mg} \mathrm{kg}^{-1} \mathrm{dm}$, respectively. A study undertaken by Vetter (2005) showed Li content in P. pulmonarius to be $0.063-0.077 \mathrm{mg} \mathrm{kg}^{-1} \mathrm{dm}$. Available literature data on mineral elements in fruit bodies of Pleurotus species are collected in Table 1 . 
Table 1 Literature data on the selected elements content $\left[\mathrm{mg} \mathrm{kg}^{-1}\right.$ dry matter $]$ in several Pleurotus species

\begin{tabular}{|c|c|c|c|c|c|c|}
\hline Element & $\begin{array}{l}P . \\
\text { ostreatus }^{\mathrm{a}}\end{array}$ & $\begin{array}{l}P . \\
\text { florida }^{\mathrm{b}}\end{array}$ & $\begin{array}{l}P . \\
\text { djamor }^{\mathrm{c}}\end{array}$ & $\begin{array}{l}P . \\
\text { citrinopileatus }^{\mathrm{d}}\end{array}$ & $\begin{array}{l}P . \\
\text { eryngii }\end{array}$ & $\begin{array}{l}P . \\
\text { pulmonarius }\end{array}$ \\
\hline $\mathrm{Ca}$ & $190-1500$ & $337-827$ & 342 & 240 & $60-700$ & $34-684$ \\
\hline K & $\begin{array}{r}21,840- \\
51,000\end{array}$ & 24,720 & $\begin{array}{r}12,300- \\
36,340\end{array}$ & 25,000 & $\begin{array}{r}14,300- \\
31,000\end{array}$ & $\begin{array}{r}23,709- \\
28,190\end{array}$ \\
\hline $\mathrm{Mg}$ & $165-2300$ & $134-359$ & $\begin{array}{l}316- \\
1210\end{array}$ & 1600 & $\begin{array}{r}1233- \\
2000\end{array}$ & $183-2593$ \\
\hline $\mathrm{Na}$ & $250-1440$ & 305 & 616 & - & $100-375$ & $310-390$ \\
\hline $\mathrm{P}$ & $\begin{array}{l}6180- \\
13,390\end{array}$ & 6402 & $\begin{array}{l}7432- \\
7570\end{array}$ & 11,000 & 1300 & $\begin{array}{l}5790- \\
23,700\end{array}$ \\
\hline $\mathrm{Ag}$ & - & - & - & - & - & 7.55 \\
\hline $\mathrm{Al}$ & $14-85$ & - & - & - & - & - \\
\hline As & $0.025-1.0$ & $0.73-0.83$ & - & - & $\begin{array}{r}0.009- \\
0.35\end{array}$ & - \\
\hline $\mathrm{Bi}$ & $1.9-9$ & - & - & - & - & - \\
\hline $\mathrm{Cd}$ & $0.28-5.39$ & 0.22 & 0.028 & - & 0.011 & - \\
\hline $\mathrm{Cr}$ & $0.1-16.3$ & - & 1.63 & - & $1.3-22.6$ & - \\
\hline $\mathrm{Cu}$ & $19-50$ & 10.6 & 14.5 & 16 & $6.83-48.5$ & - \\
\hline $\mathrm{Fe}$ & $33-550$ & $62.7-432$ & 14.0 & 95 & $24.2-190$ & $75-154$ \\
\hline $\mathrm{Hg}$ & $0.5-2.0$ & - & - & - & - & - \\
\hline $\mathrm{Li}$ & $0.044-0.208$ & - & - & - & - & $\begin{array}{r}0.063- \\
0.077\end{array}$ \\
\hline $\mathrm{Mn}$ & 5-31.4 & $6.2-27$ & 11.2 & 11 & $1.35-28.8$ & - \\
\hline $\mathrm{Ni}$ & $1.5-31.5$ & 0.7 & 1.5 & - & 0.83 & - \\
\hline $\mathrm{Pb}$ & $0.67-0.91$ & 0.92 & 1.2 & - & $0.92-2.21$ & 0.13 \\
\hline $\mathrm{Se}$ & $0.11-0.55$ & $0.132-0.48$ & 1.1 & - & - & - \\
\hline Th & - & - & - & - & - & 0.0114 \\
\hline $\mathrm{U}$ & - & - & - & - & - & 0.00325 \\
\hline $\mathrm{Zn}$ & $25-265$ & $50.6-160$ & 92.1 & 104 & $29.3-102$ & - \\
\hline
\end{tabular}

${ }^{a}$ P. ostreatus (Vetter 2005, Alam et al. 2008; Bernaś et al. 2006; Maihara et al. 2008; Muñoz et al. 2005; Kalač 2010; Costa-Silva et al. 2011 ; Zhu et al. 2011)

${ }^{\mathrm{b}}$ P. florida (Alam et al. 2008; Mallikarjuna et al. 2013)

${ }^{\mathrm{c}}$ P. djamor (Rodriguez Estrada and Royse 2007, Guo et al. 2007; Lee et al. 2009, Mallikarjuna et al. 2013)

${ }^{\mathrm{d}}$ P. citrinopileatus (Rodrigues et al. 2015)

${ }^{\text {e }}$ P. eryngii (Rodriguez Estrada and Royse 2007, Akyüz and Kirbağ 2010; Zhu et al. 2011)

${ }^{\mathrm{f}}$ P. pulmonarius (Oliveira Silva et al. 2002; Vetter 2003, 2005, Borovicka et al. 2011)

Recently, we have employed inductively coupled plasma optical emission spectrometer (ICP-OES) to investigate platinum group elements (Ir, Os, $\mathrm{Pd}, \mathrm{Pt}, \mathrm{Rh}$, and $\mathrm{Ru}$ ); light rare earth elements (Ce, $\mathrm{Gd}, \mathrm{La}, \mathrm{Nd}, \mathrm{Pr}$, and $\mathrm{Sm})$; and heavy rare earth elements (Dy, Er, Eu, Ho, Lu, Tb, Tm, Sc, Y, and Yb) in wild mushroom species growing in Poland (Mleczek et al. 2016a). In the present, a broader, multi-element ICP-OES screening (total of 62 elements) of various commercially available Pleurotus mushrooms collected over a 7 -year period (2009-2015) from Polish producers was conducted. Poland has a profound contribution to the world production of these mushrooms and this study is by far the most comprehensive insight into elemental composition of these foodstuffs.

\section{Materials and Methods}

\section{Experimental Materials}

The following $10 P$. ostreatus species/strains were analyzed as follows: $1=P$. ostreatus $80,2=P$. ostreatus H195, $3=$ P. ostreatus HK35, $4=P$. ostreatus K22, $5=$ $P$. ostreatus $930,6=P$. eryngii, $7=P$. djamor, $8=$ $P$. citrinopileatus, $9=P$. florida, and $10=$ $P$. pulmonarius. The fruit bodies of $P$. ostreatus and $P$. pulmonarius strains were collected from 19 mushroom farms. The tested fruit bodies were obtained from each mushroom grower in several cultivation cycles each year 
in the period 2009-2015. The weight of a single fruit body sample amounted to $1 \mathrm{~kg}$. Cultivation substrates of different compositions were applied by producers of oyster mushrooms in accordance with the cultivation method. The basic components of substrates were chopped wheat and rye straw. The substrates were supplemented with wheat bran, corncobs, sunflower seed hulls, and chalk by some mushroom growers depending on the cultivation method they used. The fruit bodies of $P$. djamor, P. citrinopileatus, P. florida, and P. eryngii were collected from 19 experimental cultivations in the Vegetable Crop Department of Poznań University of Life Sciences. As in the case of $P$. ostreatus, fruit bodies originated from several harvests during each year from the period 2009-2015. Each sample consisted of $0.25 \mathrm{~kg}$ of fruit bodies. $P$. djamor, $P$. citrinopileatus, and $P$. florida were cultivated on substrates of wheat straw with different additives. Supplements such as sawdust from deciduous trees, wheat and rye bran, flax shives, hemp shives, corn meal, soybean meal, and chalk were applied in different proportions in relation to the cultivation conditions. P. eryngii, on the other hand, was cultivated on substrates from a mixture of beech (Fagus sylvatica L.), alder (Alnus glutinosa Gaertn.), oak (Quercus robur L.). and birch (Betula pendula Roth) sawdust in different proportions. Sawdust substrates were supplemented as in the above-mentioned Pleurotus species. Gypsum was an additional component. Fruiting bodies were collected each year from several experimental cultivations in the amount of $0.25 \mathrm{~kg}$ in each replication.

\section{Sample Processing}

Ten samples of ten different Pleurotus species/strains were collected for analysis. Fruiting bodies from the first harvest of each year only were collected, as it was possible to collect the fruiting bodies of all 10 species/strains from the same places simultaneously (700 samples in total). In the case of the other harvests, fruiting bodies were not produced by the selected species so comparison of all 10 mushroom species was not possible and this material was not analyzed. Deionized ultrapure water (Milli-Q, Millipore, Saint Louis, USA) was used. Samples were dried at $105 \pm 5{ }^{\circ} \mathrm{C}$ for $90 \mathrm{~h}$ in an electric oven (SLW 53 STD, Pol-Eko, Wodzisław Śląski, Poland) and ground in a laboratory Cutting Mill SM 200 (Retsch GmbH, Haan, Germany). Then, $0.400 \pm 0.001 \mathrm{~g}$ of a dry sample was digested with concentrated nitric acid $(65 \%$ nitric acid, Merck, Darmstadt, Germany) in closed Teflon containers in the microwave digestion system Mars 5 Xpress (CEM, Matthews, USA). Samples were then filtered through paper filters and diluted with water to a final volume of $15.0 \mathrm{~mL}$. Each of the samples was processed in 29 replicates.

\section{Instruments and Quality Control}

The inductively coupled plasma optical emission spectrometer Agilent 5100 ICP-OES (Agilent, USA) was used for the determination of 62 elements under common conditions, which are listed in the Supplementary data (Table S1). ICP commercial analytical standards (Romil, England) were applied for the calibration. The selected wavelengths and validation parameters were as follows: the detection limits obtained follow 3-sigma criteria on the level of $0.0 X \mathrm{mg} \mathrm{kg}^{-1}$ dry matter (dm), precision and upper range of calibration curves are collected in Supplementary data (Table S2). Uncertainty for the complete analytical process (including sample preparation) was at the level of $20 \%$. Traceability was checked using the standard reference materials CRM S- 1 = loess soil; CRM NCSDC (73349) = bush branches and leaves; CRM $2709=$ soil; CRM 405 = estuarine sediments; and CRM $667=$ estuarine sediments. The recovery $(80-120 \%)$ was acceptable for all the elements determined and detailed data is listed in Supplementary data (Table S3). Each of the samples was analyzed in triplicate.

\section{Statistical Analysis}

To compare the content of individual elements in the analyzed Pleurotus species within the tested period, the obtained data were illustrated using Heatmaps, where two-dimensional variables (mushroom species, element) were shown in color. Prepared figures allowed the similarities between tested mushroom species as regards to their ability to accumulate elements to be determined.

Cluster analysis allowed Pleurotus species to be separated as regards to element contents within the 7 years of studies (2009-2015) jointly but also separately for each year. This way to explain similarity inside groups was the most efficient among the groups. Using Ward Hierarchical Clustering and analysis of Euclidean distances, three plots were prepared.

\section{Results}

Among the 62 elements analyzed in the tested mushrooms, only 31 of them (Al, As, B, Ca, Cd, Cr, Cu, Er, Fe, In, K, Lu, $\mathrm{Mg}, \mathrm{Mn}, \mathrm{Na}, \mathrm{Nd}, \mathrm{P}, \mathrm{Pb}, \mathrm{Pt}, \mathrm{Re}, \mathrm{Rh}, \mathrm{Sc}, \mathrm{Se}, \mathrm{Sr}, \mathrm{Te}, \mathrm{Th}, \mathrm{Ti}, \mathrm{Tm}$, $\mathrm{U}, \mathrm{Zn}$, and $\mathrm{Zr}$ ) were measurable in fruit bodies in each year of the collection period. In the case of the rest of the elements (Ag, Au, Ba, Be, Bi, Ce, Co, Dy, Eu, Ga, Gd, Ge, Hf, Ho, Ir, $\mathrm{La}, \mathrm{Li}, \mathrm{Mo}, \mathrm{Ni}, \mathrm{Os}, \mathrm{Pd}, \mathrm{Pr}, \mathrm{Rb}, \mathrm{Ru}, \mathrm{Sb}, \mathrm{Sm}, \mathrm{Tb}, \mathrm{Tl}, \mathrm{V}, \mathrm{Y}$, and $\mathrm{Yb}$ ) their content in numerous fruit bodies was below the limit of detection. The ability to accumulate the determined elements in the tested mushroom species varies widely (Table 2). 
Table 2 Mean, the lowest and the highest content of analyzed elements $\left[\mathrm{mg} \mathrm{kg}^{-1}\right.$ dry matter] in Pleurotus species

\begin{tabular}{|c|c|c|c|c|c|}
\hline Element & The lowest content & & Mean & The highest content & \\
\hline $\mathrm{Al}$ & P. ostreatus 930 & 0.60 & 4.39 & 44.14 & P. ostreatus $\mathrm{K} 22$ \\
\hline As & P. ostreatus HK35 & 0.04 & 0.86 & 3.59 & P. eryngii \\
\hline $\mathrm{B}$ & P. ostreatus 80 & 0.07 & 3.65 & 24.80 & P. eryngii \\
\hline $\mathrm{Ca}$ & P. florida & 37 & 157 & 2204 & P. eryngii \\
\hline $\mathrm{Cd}$ & P. ostreatus $\mathrm{H} 195$ & 0.06 & 0.47 & 5.54 & P. ostreatus 80 \\
\hline $\mathrm{Cr}$ & P. florida & 0.07 & 0.28 & 1.55 & P. ostreatus $\mathrm{K} 22$ \\
\hline $\mathrm{Cu}$ & P. eryngii & 3 & 15 & 54 & P. ostreatus 930 \\
\hline $\mathrm{Er}$ & P. pulmonarius & 0.06 & 0.38 & 1.60 & P. ostreatus $\mathrm{K} 22$ \\
\hline $\mathrm{Fe}$ & P. ostreatus 930 & 18 & 105 & 775 & P. ostreatus $\mathrm{K} 22$ \\
\hline In & P. ostreatus $\mathrm{K} 22$ & 0.05 & 0.31 & 1.07 & P. eryngii \\
\hline K & P. florida & 10,970 & 26,050 & 56,710 & P. djamor \\
\hline $\mathrm{Lu}$ & P. pulmonarius & 0.01 & 0.02 & 0.05 & P. ostreatus 930 \\
\hline $\mathrm{Mg}$ & P. pulmonarius & 918 & 2190 & 5145 & P. citrinopileatus \\
\hline $\mathrm{Mn}$ & P. ostreatus 930 & 4 & 12 & 27 & P. citrinopileatus \\
\hline $\mathrm{Na}$ & P. citrinopileatus & 11 & 87 & 348 & P. eryngii \\
\hline $\mathrm{Nd}$ & P. florida & 0.02 & 0.41 & 7.18 & P. eryngii \\
\hline $\mathrm{P}$ & P. ostreatus 930 & 4033 & 13,490 & 33,320 & P. citrinopileatus \\
\hline $\mathrm{Pb}$ & P. ostreatus H195 & 0.02 & 0.50 & 2.46 & P. ostreatus 80 \\
\hline $\mathrm{Pt}$ & P. ostreatus 80 & 0.10 & 1.16 & 8.87 & P. ostreatus $\mathrm{K} 22$ \\
\hline $\mathrm{Re}$ & P. pulmonarius & 0.05 & 0.23 & 0.62 & P. citrinopileatus \\
\hline $\mathrm{Rh}$ & P. pulmonarius & 0.01 & 0.10 & 0.60 & P. florida \\
\hline $\mathrm{Sc}$ & P. pulmonarius & 0.01 & 0.03 & 0.13 & P. ostreatus $\mathrm{H} 195$ \\
\hline $\mathrm{Se}$ & P. ostreatus 930 & 0.09 & 1.16 & 4.09 & P. citrinopileatus \\
\hline $\mathrm{Sr}$ & P. pulmonarius & 0.02 & 0.37 & 6.63 & P. eryngii \\
\hline $\mathrm{Te}$ & P. florida & 0.33 & 2.22 & 6.41 & P. ostreatus HK35 \\
\hline $\mathrm{Th}$ & P. eryngii & 0.01 & 0.15 & 0.38 & P. ostreatus $\mathrm{K} 22$ \\
\hline $\mathrm{Ti}$ & P. pulmonarius & 0.03 & 0.14 & 0.57 & P. ostreatus $\mathrm{K} 22$ \\
\hline $\mathrm{Tm}$ & P. pulmonarius & 0.01 & 0.05 & 0.19 & P. ostreatus $\mathrm{K} 22$ \\
\hline $\mathrm{U}$ & P. ostreatus $\mathrm{H} 195$ & 0.06 & 1.00 & 4.09 & P. citrinopileatus \\
\hline $\mathrm{Zn}$ & P. florida & 19 & 95 & 311 & P. djamor \\
\hline $\mathrm{Zr}$ & P. pulmonarius & 0.01 & 0.04 & 0.54 & P. ostreatus $\mathrm{H} 195$ \\
\hline
\end{tabular}

The lowest contents of Al, Fe, Mn, P, and Se were observed in the strain P. ostreatus 930 ; those of $\mathrm{Ca}, \mathrm{Cr}, \mathrm{K}$, $\mathrm{Nd}, \mathrm{Te}$, and $\mathrm{Zn}$ in P. florida; and of rarely reported elements $\mathrm{Er}, \mathrm{Rh}, \mathrm{Sc}, \mathrm{Tm}$ and $\mathrm{Zr}$ in $P$. pulmonarius. $P$. ostreatus 930 displayed the highest content of $\mathrm{Cu}$ and $\mathrm{Lu}$, and P. florida of $\mathrm{Rh}$. A more distinct situation was observed for the other three Pleurotus species (P. ostreatus $\mathrm{K} 22$, $P$. citrinopileatus, and $P$. eryngii). The highest contents of $\mathrm{Al}, \mathrm{Cr}, \mathrm{Er}, \mathrm{Fe}, \mathrm{Pt}, \mathrm{Th}, \mathrm{Ti}$, and Tm were determined in P. ostreatus $\mathrm{K} 22$; those of $\mathrm{Mg}, \mathrm{Mn}, \mathrm{P}, \mathrm{Re}, \mathrm{Se}$ and $\mathrm{U}$ in P. citrinopileatus, whereas $P$. eryngii was shown to contain the highest levels of $\mathrm{As}, \mathrm{B}, \mathrm{Ca}, \mathrm{In}, \mathrm{Na}, \mathrm{Nd}$ and $\mathrm{Sr}$. Additionally, these three species were characterized by the lowest contents of In (P. ostreatus K22), Na (P. citrinopileatus), and Th (P. eryngii).

Within the rest of the tested species/strains, $P$. ostreatus HK35 contained the lowest content of As and the highest Te level, P. ostreatus $\mathrm{H} 195$ the lowest content of $\mathrm{Cd}, \mathrm{Pb}$, and $\mathrm{U}$ and the highest $\mathrm{Sc}$ level. It is worth emphasizing that the highest content of $\mathrm{Cd}$ and $\mathrm{Pb}$ was observed in fruit bodies of P. ostreatus 80. P. djamor was the most effective accumulator of $\mathrm{K}$ and $\mathrm{Zn}$. 
Fig. 1 Comparison of Pleurotus species with regard to mean content of 31 elements (Heatmap) within 2009-2015

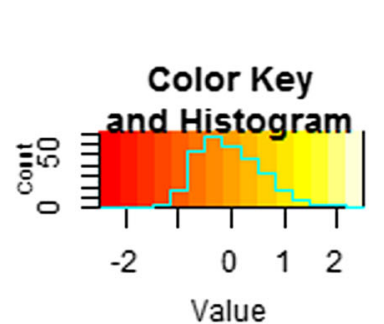

1 - P. ostreatus 80

$6-$ P. eryngii

$2-P$ ostreatus $\mathrm{H195} \quad 7-P$. djamor

3 - P. ostreatus HK35 8-P. citrinopileatus

4-P. ostreatus K22 9-P. florida

5 - P. ostreatus 930

10 - P. pulmonarius

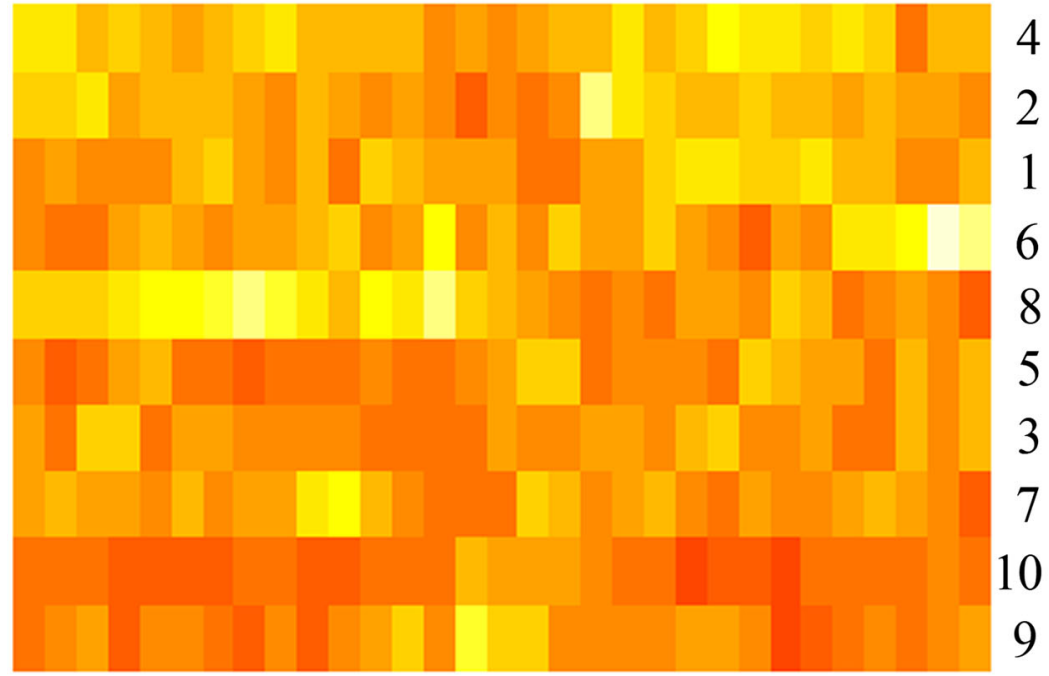

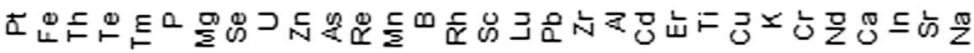

To show the real similarities and differences in the content of particular elements determined in fruit bodies throughout the years of sample collection, a Heatmap was performed and the obtained results are presented in Fig. 1.

The same color in column indicates no differences in the content of the same element between tested Pleurotus species. This presentation was widened to show how these similarities or differences were revealed in particular years of mushroom production (Supplementary data, Fig. S1). To illustrate general differences between these species as regards to their content of all the analyzed elements, cluster analysis was used for preparation of the cluster dendrogram presented in Fig. 2.
Three significantly diverse groups of Pleurotus species were assigned. $P$. florida and P. pulmonarius were included in the first group as significantly different from the rest. The second group comprised $P$. ostreatus HK35, P. ostreatus 930, $P$. eryngii, and $P$. djamor while the third included $P$. ostreatus 80, P. ostreatus $\mathrm{H} 195$, P. ostreatus $\mathrm{K} 22$, and P. citrinopileatus. The differences between the tested mushroom species/strains and their insertion into the uniform groups in particular years are presented in Fig. 3.

The significance of the presented data relates to the variability in mushroom species assigned to the groups in particular years. The clearest relationships were observed for two

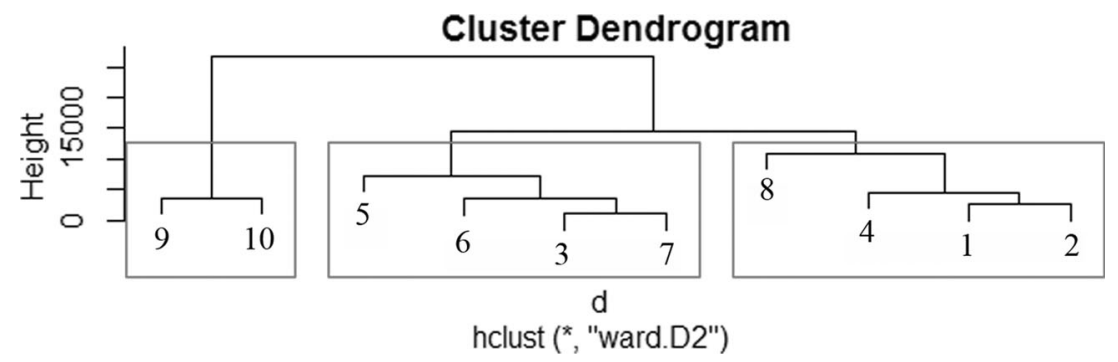

Fig. 2 A hierarchical tree plot showing the groups of mushrooms characterized by a high similarity in the accumulation of all 31 elements jointly. 1 P. ostreatus 80; 2 P. ostreatus H195; 3 P. ostreatus HK35; 4 P.

ostreatus K22; 5 P. ostreatus 930; 6 P. eryngii; 7 P. djamor; 8 P. citrinopileatus; 9 P. florida; 10 P. pulmonarius 

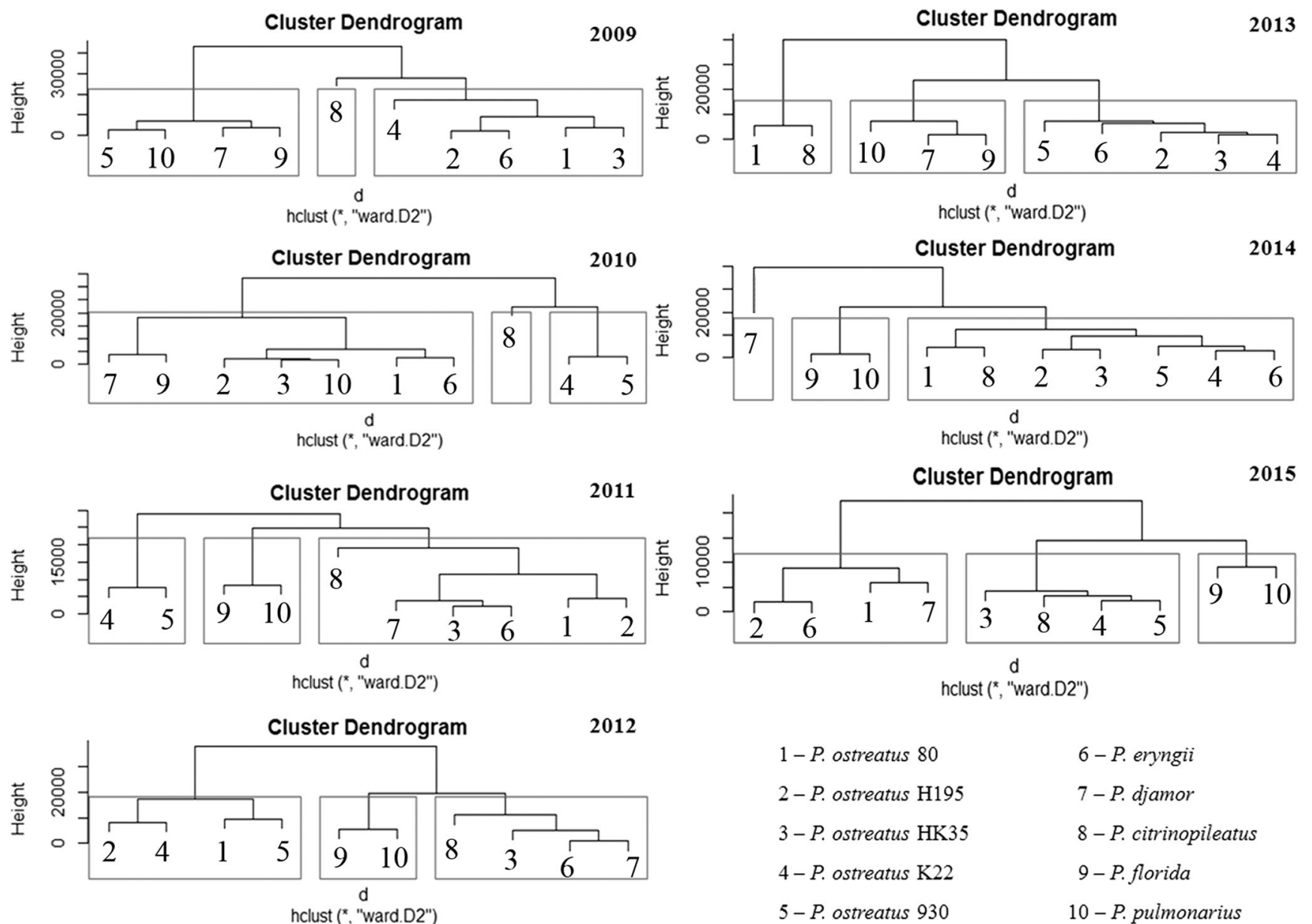

$$
\begin{aligned}
& 1-P . \text { ostreatus } 80 \\
& 2-P . \text { ostreatus } \mathrm{H} 195 \\
& 3-P . \text { ostreatus } \mathrm{HK} 35 \\
& 4-P . \text { ostreatus } \mathrm{K} 22 \\
& 5-P . \text { ostreatus } 930
\end{aligned}
$$

$$
\begin{aligned}
& 6-P . \text { eryngii } \\
& 7-P . \text { djamor } \\
& 8-P . \text { citrinopileatus } \\
& 9-P . \text { florida } \\
& 10-P . \text { pulmonarius }
\end{aligned}
$$

Fig. 3 A hierarchical tree plot showing the groups of mushrooms characterized by a high similarity in the accumulation of all 31 elements jointly in particular years of mushroom cultivation

pairs of mushrooms: P. ostreatus 80 and P. ostreatus $\mathrm{H} 195$ and P. florida and P. pulmonarius. In the former pair, the content of all 31 elements in P. ostreatus 80 and P. ostreatus $\mathrm{H} 195$ fruit bodies collected in all years was similar with the exception of 2013, while the latter pair of $P$. ostreatus strains belonged to the same group every year. These data suggest that the substrate used by the mushroom producers for the cultivation of Pleurotus mushrooms plays a considerable role.

\section{Discussion}

\section{Content of Elements in Pleurotus Fruit Bodies}

The present study is so far the broadest investigation of the multi-element content in fruit bodies of cultivated mushrooms belonging to the Pleurotus genus. As demonstrated, the investigated species/strains generally varied from each other in terms of element accumulation, not only in observed contents but also in their rank of order. Furthermore, the same species/ strains collected during different seasons were also found to vary mutually. Hence, the present study suggests that the commercial substrates available for mushroom producers can exert a considerable influence on the chemical composition of Pleurotus mushroom fruit bodies. In fact, the number of different materials and their additions that can be used to cultivate these species is very large. The composition of substrate plays a crucial role in mineral element uptake and accumulation, including toxic elements, in consumable mushroom parts. As previously shown, the addition of various elements, both non-essential and nutritional, to cultivation substrate usually results in a proportional increase in their content in fruit bodies (Mleczek et al. 2016b; Rzymski et al. 2016a, b). Considering the popularity of Pleurotus mushrooms for global mushroom production as a foodstuff, it is of high interest to screen their chemical content and to assess whether they may contain potentially toxic levels of certain elements.

The mean contents of detected elements in the fruit bodies of the investigated species generally decreased in the following order $\mathrm{K}>\mathrm{P}>\mathrm{Mg}>\mathrm{Ca}>\mathrm{Fe}>\mathrm{Na}>\mathrm{Zn}>\mathrm{Cu}>\mathrm{Al}>\mathrm{Mn}>$ $\mathrm{B}>\mathrm{Pt}>\mathrm{Nd}>\mathrm{Sr}>\mathrm{Te}>\mathrm{Cd}>\mathrm{Se}>\mathrm{U}>\mathrm{As}>\mathrm{Pb}>\mathrm{Er}>\mathrm{Cr}>\mathrm{In}$ $>\mathrm{Re}>\mathrm{Rh}>\mathrm{Ti}>\mathrm{Zr}>\mathrm{Th}>\mathrm{Tm}>\mathrm{Sc}>\mathrm{Lu}$. Based on the 
identified contents, five main groups of elements could be classified (expressed per dry weight): (i) those exceeding $1000 \mathrm{mg} \mathrm{kg}^{-1}$ (K, P, Mg, and Ca); (ii) ranging from 100 to $1000 \mathrm{mg} \mathrm{kg}^{-1}$ (Fe, Na, $\mathrm{Zn}$ ); (iii) ranging from 10 to $100 \mathrm{mg} \mathrm{kg}^{-1}(\mathrm{Cu}, \mathrm{Al}, \mathrm{Mn}, \mathrm{B})$; (iv) ranging from 1 to $10 \mathrm{mg} \mathrm{kg}^{-1}$ (Pt, Nd, Sr, Te, Cd, Se, U, As, Pb, Er, Cr, In); and (v) below $1 \mathrm{mg} \mathrm{kg}^{-1}$ (Re, Rh, Ti, Zr, Th, Tm, Sc, Lu).

\section{Characteristics of Potential Health Risks}

Apart from rate of element accumulation in fruit bodies of the investigated species, it is of high interest to assess whether the identified levels of toxic or potentially toxic elements can pose a potential risk for human health following consumption of such mushrooms. Besides nutritionally essential elements, the present study evaluated the content of $\mathrm{Al}, \mathrm{As}, \mathrm{Cd}$, and $\mathrm{Pb}$, which can be considered as nonspecific for human metabolism and further, toxic at certain levels. Moreover, rare earth elements (REEs), whose health risk is still unknown, require an evaluation. REEs are increasingly emitted mostly from industry and include such elements as $\mathrm{La}, \mathrm{Ce}, \mathrm{Pr}, \mathrm{Nd}, \mathrm{Sm}, \mathrm{Eu}, \mathrm{Gd}, \mathrm{Tb}, \mathrm{Dy}, \mathrm{Ho}, \mathrm{Er}$, Tm, Yb, Lu, Sc, and Y (Gambogi 2011; Li et al. 2013). The present study evaluated the content of five REEs (Er, Nd, $\mathrm{Tm}, \mathrm{Lu}$, and Sc). According to our knowledge, the only regulation for total REEs in foodstuffs was set in China at $0.7 \mathrm{mg} \mathrm{kg}^{-1}$ fresh weight (SAC 2005, 2012). The total mean content of five REEs in the investigated Pleurotus mushrooms exceeded this level $\left(0.9 \mathrm{mg} \mathrm{kg}^{-1}\right.$ dry weight). Most striking, however, was the relatively high content of $\mathrm{Nd}$, which at its maximal level found in P. eryngii, was over $8 \mathrm{mg} \mathrm{kg}^{-1}$ dry weight. This is over three times more than the highest Nd level determined so far in wild mushrooms (Mleczek et al. 2016a). This finding indicates that even some cultivated mushrooms may be a significant source of $\mathrm{Nd}$ - an element which can act as an anticoagulant and which is considered to be moderately toxic, even though further evaluation of its biological activity is necessary.

The provisional tolerable weekly intake (PTWI) for $\mathrm{Al}$ is $2 \mathrm{mg} \mathrm{kg}^{-1}$ bodyweight (JECFA 2012). Considering an average single serving is $300 \mathrm{~g}$ of fresh mushrooms, i.e., about $30 \mathrm{~g}$ of dry matter (as a $10 \%$ level is used for calculations with an unknown factual dm level), the mean and maximal content determined in the investigated mushrooms (4.4 and $44.1 \mathrm{mg} \mathrm{kg}^{-1} \mathrm{dm}$ ) would contribute insignificantly to PTWI for an adult weighing $60 \mathrm{~kg}$.

The content of As was also too low to contribute significantly to As exposure through consumption of the investigated species. This is important if one considers that $P$. eryngii and $P$. ostreatus were previously shown to accumulate very high levels of As from artificially contaminated substrate (Mleczek et al. 2016b). The PTWI of total As was set at
$15 \mu \mathrm{g} \mathrm{kg}^{-1}$ bodyweight (JECFA 1988) but this was later revised because the lower limit on the benchmark dose for a $0.5 \%$ increasing incidence of lung cancer was in a similar range (FAO and WHO 2011). Nevertheless, the maximum level of As in Pleurotus mushrooms would account for $11.9 \%$ of PTWI (considering that $30 \mathrm{~g} \mathrm{dm}$ would be consumed by a $60-\mathrm{kg}$ adult). It is also important to highlight that the toxicity of As largely depends on its chemical species; therefore, the risk of any adverse effects from As, following the consumption of the investigated mushrooms, was very low.

The provisional tolerable monthly intake (PTMI) of Cd was set at $0.025 \mathrm{mg} \mathrm{kg}^{-1}$ bodyweight (JECFA 2011), which accounts to $1.5 \mathrm{mg}$ per month for a $60-\mathrm{kg}$ adult. In this case, the risk of adverse $\mathrm{Cd}$ exposure was also very low if one considers that the mean and maximum level of this element found in the investigated mushrooms would account for 0.7 and $11.3 \%$, respectively (when $30 \mathrm{~g} \mathrm{dm}$ is consumed by a $60-\mathrm{kg}$ individual).

It should, however, be pointed out that $\mathrm{Pb}$ contents in fruit bodies of the investigated mushrooms were relatively high. The WHO determines the PTWI of lead at $0.025 \mathrm{mg} \mathrm{kg}^{-1}$ bodyweight (and equivalent of $0.0036 \mathrm{mg} \mathrm{kg}^{-1}$ body weight per day) (JECFA 2011), i.e., $1.5 \mathrm{mg}$ weekly (and $0.21 \mathrm{mg}$ daily) for an adult weighing $60 \mathrm{~kg}$. The maximum determined $\mathrm{Pb}$ content of $2.46 \mathrm{mg} \mathrm{kg}^{-1} \mathrm{dm}$ in P. ostreatus 80 would thus deliver a dose of $0.074 \mathrm{mg}$ from a serving of $300 \mathrm{~g}$ of the fresh fruit bodies. This indicates that some substrates used for $P$. ostreatus cultivation could be contaminated with $\mathrm{Pb}$. It is worth noting that the screening of commercially available mushrooms in China also revealed that $P$. ostreatus contained the highest $\mathrm{Pb}$ levels - a finding related to the substrate applied for cultivation (Huang et al. 2015). Overall, this highlights the need to check $\mathrm{Pb}$ content in these mushrooms and more particularly, the composition of substrates used for their cultivation. On the other hand, one should consider that the bioaccessibility of toxic elements from the investigated mushrooms in the human gastrointestinal tract can be reduced by cooking treatments such as boiling or microwaving with water (Sun et al. 2012).

\section{Conclusions}

The present study indicated that there are significant differences in element accumulation by different commercially cultivated species of the genus Pleurotus. Importantly, the levels of most of toxic elements were low apart from $\mathrm{Pb}$ contents, which were of some concern and highlighted the need to check substrates used for cultivation of these mushrooms. The strikingly high content of Nd, an element of as yet incompletely elucidated toxicity, was found in some mushrooms. 


\section{Compliance with Ethical Standards}

Funding This work was partially funded by the Polish Ministry of Science and Higher Education under grant N N305 372538. Piotr Rzymski is supported by the Foundation for Polish Science within the "Start" Program.

Conflict of Interest Marek Siwulski declares that he has no conflict of interest. Mirosław Mleczek declares that he has no conflict of interest, Piotr Rzymski declares that he has no conflict of interest, Anna Budka declares that he has no conflict of interest, Agnieszka Jasińska declares that he has no conflict of interest, Przemysław Niedzielski declares that he has no conflict of interest, Pavel Kalač declares that he has no conflict of interest, Monika Gąsecka declares that he has no conflict of interest, Sylwia Budzyńska declares that he has no conflict of interest, Patrycja Mikołajczak declares that he has no conflict of interest.

Ethical Approval This article does not contain any studies with human participants or animals performed by any of the authors.

Open Access This article is distributed under the terms of the Creative Commons Attribution 4.0 International License (http:// creativecommons.org/licenses/by/4.0/), which permits unrestricted use, distribution, and reproduction in any medium, provided you give appropriate credit to the original author(s) and the source, provide a link to the Creative Commons license, and indicate if changes were made.

\section{References}

Akyüz M, Yildiz A (2008) Evaluation of cellulosic wastes for the cultivation of Pleurotus eryngii (DC. Ex Fr.) Quel. Afr J Biotechnol 7: 1494-1499

Akyüz M, Kirbağ S (2010) Effect of various agro-residues on nutritive value of Pleurotus eryngii (DC. Ex Fr.) Quel. Var. Ferulae Lanzi. J Agric Sci 16:83-88

Alam N, Amin R, Khan A, Ara I, Shim MJ, Lee MW, Lee TS (2008) Nutritional analysis of cultivated mushrooms in BangladeshPleurotus ostreatus, Pleurotus sajor-caju, Pleurotus florida and Calocybe indica. Mycobiology 36:228-232

Bernaś E, Jaworska G, Lisiewska Z (2006) Edible mushrooms as a source of valuable nutritive constituents. Acta Sci Pol Technol Aliment 5: $5-20$

Borovicka J, Kubrova J, Rohovec J, Randa Z, Dunn CE (2011) Uranium, thorium and rare earth elements in macrofungi: what are the genuine concentrations? Biometals 24:837-845

Brunnert H, Zadrazil F (1983) The translocation of mercury and cadmium into the fruit bodies of six higher fungi. A comparative study on species specificity in five lignocellulolytic fungi and the cultivated mushroom Agaricus bisporus. Eur J Appl Microbiol Biotechnol 17: 358-366

Chang ST (1999) World production of cultivated edible and medicinal mushrooms in 1997 with emphasis on Lentinus edodes (Berk.) sing. In China. Int J Med Mush 1:291-300

Chaubey A, Dehariya P, Vyas D (2010) Seasonal productivity and morphological variation in Pleurotus djamor. Indian J Sci Res 1:47-50

Chauhan M (2013) Bioaccumulation of lead content in mushroom and soil in Delhi-NCR region of India. Chem Sci Trans 2:1288-1295

Costa-Silva F, Marques G, Matos CC, Barros A, Nunes FM (2011) Selenium contents of Portuguese commercial and wild edible mushrooms. Food Chem 126:91-96

Cordeiro F, Llorente-Mirandes T, López-Sánchez JF, Rubio R, Sánchez Agullo A, Raber G, Scharf H, Vélez D, Devesa V, Fiamegos Y,
Emteborg H, Seghers J, Robouch P, de la Calle MB (2015) Determination of total cadmium, lead, arsenic, mercury and inorganic arsenic in mushrooms: outcome of IMEP-116 and IMEP-39. Food Addit Contam Part A 32:54-67

Daba AS, Kabeil SS, Botros WA, El-Saadani MA (2008) Production of mushroom (Pleurotus ostreatus) in Egypt as a source of nutritional and medicinal food. WJAS 4:630-634

Deepalakshmi K, Mirunalini S (2014) Pleurotus ostreatus: an oyster mushroom with nutritional and medicinal properties. J Biochem Tech 5:718-726

Dundar A, Acay H, Yildiz A (2008) Yield performances and nutritional contents of three oyster mushroom species cultivated on wheat stalk. Afr J Biotechnol 7:3497-3501

FAO and WHO (2011) Safety evaluation of certain contaminants in food. WHO food additive series 63/FAO JECFA monographs 7 . WHO Press, Geneva

Gambogi J (2011) Rare earths. U.S. Geological Survey minerals yearbook - 2011. 60-60.12. USGE, Reston (Va)

Gonzalez P, Labarere J (2000) Phylogenetic relationships of Pleurotus species according to the sequence and secondary structure of the mitochondrial small-subunit rRNA V4, V6 and V9 domains. Microbiology 146:209-221

Gucia M, Kojta AK, Jarzyńska G, Rafał E, Roszak M, Osiej I, Falandysz J (2012) Multivariate analysis of mineral constituents of edible parasol mushroom (Macrolepiota procera) and soils beneath fruiting bodies collected from northern Poland. Environ Sci Pollut Res 19: 416-431

Guo L-Q, Lin J-Y, Lin J-F (2007) Non-volatile components of several novel species of edible fungi in China. Food Chem 100:643-649

Hassan FRH, Medany GM, Hussein A (2010) Cultivation of the king oyster mushroom (Pleurotus eryngii) in Egypt. Aust J Basic Appl Sci 4:99-105

Hong J, Bañuelos GS, Fowler T, Lin Z-Q 2011 Use of selenium-laden plant materials from phytoremediation to produce seleniumbiofortified edible mushrooms. ICOBTE 2011, 11th International Conference on the Biogeochemistry of Trace Elements. Conference Proceedings, Part I, Congress Center, Florence, Italy, July 3-7, pp 349-350

Huang Q, Jia Y, Wan Y, Li H, Jiang R (2015) Market survey and risk assessment for trace metals in edible fungi and the substrate role in accumulation of heavy metals. J Food Sci 80:1612-1618

JECFA 1988 658. Arsenic. WHO Food Additive Series 24

JECFA 2011 Safety evaluation of certain contaminants in food, prepared by the seventy-second meeting of the Joint FAO/WHO Expert Committee on Food Additives (JECFA) WHO Food Additives Series, vol. 959

JECFA 2012 Safety evaluation of certain food additives/prepared by the seventy fourth meeting of the Joint FAO/WHO Expert Committee on Food Additives (JECFA) WHO Food Additives Series, vol. 65

Kalač P (2010) Trace element contents in European species of wild growing edible mushrooms: a review for the period 2000-2009. Food Chem 122:2-15

Kalač P (2016) Edible mushrooms. Chemical composition and nutritional value. Academic Press/Elsevier, Amsterdam

Kirbag S, Akyüz M (2008) Evaluation of agricultural wastes for the cultivation of Pleurotus eryngii (DC. Ex Fr.) Quel. Var. Ferulae Lanzi. Afr J Biotechnol 7:3660-3664

Lee CY, Park JE, Kim BB, Kim SM, Ro HS (2009) Determination of mineral components in the cultivation substrates of edible mushrooms and their uptake into fruiting bodies. Mycobiology 37:109113

Li Y (2012) Present development situation and tendency of edible mushroom industry in China. Mushroom Sci 18:3-9

Li X, Chen Z, Chen Z, Zhang Y (2013) A human health risk assessment of rare earth elements in soil and vegetables from a mining area in Fujian Province, Southeast China. Chemosphere 93:1240-1246 
Maihara VA, Moura PL, Catharino MG, Castro LP, Figueira RCL (2008) Arsenic and cadmium content in edible mushrooms from São Paulo, Brazil determined by INAA and GFAAS. J Radioanal Nucl Chem 278:395-397

Mallikarjuna SE, Ranjini A, Haware DJ, Vijayalakshmi MR, Shashirekha MN, Rajarathnam S (2013) Mineral composition of four edible mushrooms. J Chem 2013:805284

Mikiashvili N, Wasser S, Nevo E, Chichua D, Elisashvili V (2004) Lignocellulolytic enzyme activities of medicinally important basidiomycetes from different ecological niches. Int J Med Mushrooms 6: 63-71

Mleczek M, Niedzielski P, Kalač P, Siwulski M, Rzymski P, Gąsecka M (2016a) Levels of platinum group elements and rare-earth elements in wild mushroom species growing in Poland. Food Addit Contam A 33:86-94

Mleczek M, Niedzielski P, Siwulski M, Rzymski P, Gąsecka M, Goliński P, Kozak L, Kozubik T (2016b) Importance of low substrate arsenic content in mushroom cultivation and safety of final food product. Eur Food Res Technol 242:355-362

Moonmoon M, Uddin Md N, Ahmed S, Shelly NJ, Khan MA (2010) Cultivation of different strains of king oyster mushroom (Pleurotus eryngii) on sawdust and rice straw in Bangladesh. Saudi J Biol Sci $17: 341-345$

Muñoz AHS, Corona FG, Wrobel K, Soto GM, Wrobel K (2005) Subcellular distribution of aluminum, bismuth, cadmium, chromium, copper, iron, manganese, nickel, and lead in cultivated mushrooms (Agaricus bisporus and Pleurotus ostreatus). Biol Trace Elem Res 106:265-277

Naik V, Sharma D, Kumar P, Yadav R (2012) Efficacy of lignocellulolytic fungi on recycling semicultural waste. Acta Biol Indica $1: 47-50$

Nnorom IC, Jarzyńska G, Falandysz J, Drewnowska M, Okoye I, OjiNnorom CG (2012) Occurrence and accumulation of mercury in two species of wild grown Pleurotus mushrooms from southeastern Nigeria. Ecotoxicol Environ Saf 84:78-83

Nnorom IC, Jarzyńska G, Falandysz J, Drewnowska M, Pankavec S, Kojta AK (2013) Analysis of twenty major and trace elements in sclerotium of Pleurotus tuber-regium (Ósū) mushroom from southeastern Nigeria. J Food Compos Anal 29:73-81

Oliveira Silva S, Gomes da Costa S, Clemente E (2002) Chemical composition of Pleurotus pulmonarius (Fr.) Quél., substrates and residues after cultivation. Braz Arch Biol Technol 45:532-535

Qi T, Zhiqiang W, Jihong Ch, Quian G, Lingang G 2007 Edible Fungi Institute, Shanghai Academy of Agricultural Sciences

Rodrigues DMF, Freitas AC, Rocha-Santos TAP, Vasconcelos MW, Roriz M, Rodríguez-Alcalá LM, Gomes AMP, Duarte AC (2015) Chemical composition and nutritive value of Pleurotus citrinopileatus var cornucopiae, $P$. eryngii, $P$. salmoneo stramineus, Pholiota nameko and Hericium erinaceus. J Food Sci Technol 52: 6927-6939
Rodriguez Estrada AE, Royse DJ (2007) Yield, size and bacterial blotch resistance of Pleurotus eryngii grown on cottonseed hulls/oak sawdust supplemented with manganese, copper and whole ground soybean. Bioresour Technol 98:1898-1906

Royse DJ (2014) A global perspective on the high five: Agaricus, Pleurotus, Lentinula, Auricularia \& Flammulina. In: Singh M (ed) Proceedings of the 8th international conference on mushroom biology and mushroom products, New Delhi, India, pp. 1-6

Royse DJ 2013 Trends in mushroom production worldwide. In: Proceedings of the 7th International Symposium on Mushrooms in Brazil, Manaus, Brazil. p 38-47

Rzymski P, Mleczek M, Niedzielski P, Siwulski M, Gąsecka M (2016a) Potential of cultivated Ganoderma lucidum mushrooms for the production of supplements enriched with essential elements. J Food Sci 81:587-592

Rzymski P, Mleczek M, Siwulski M, Gąsecka M, Niedzielski P (2016b) The risk of high mercury accumulation in edible mushrooms cultivated on contaminated substrates. J Food Compos Anal. doi:10.1016/j.jfca.2016.06.009

SAC 2005 Standardization Administration of the People's Republic of China. Maximum levels of contaminants in foods; GB 2762-2005

SAC 2012 Standardization Administration of the People's Republic of China. Maximum levels of contaminants in foods; GB 2762-2012

Sanchez JE, Mata G 2012 Hongos Comestibles en Iberoamérica: investigacion y desarrollo en unentorno multicultural. El Colegio de la Frontera Sur. Tapachula, México. [in Spanish]

Sun L, Liu G, Yang M, Zhuang Y (2012) Bioaccessibility of cadmium in fresh and cooked Agaricus blazei Murill assessed by in vitro biomimetic digestion system. Food Chem Toxicol 50:1729-1733

United States Department of Agriculture (USDA) 2014 Mushrooms. National Agricultural Statistics Service, Agricultural Statistics Board, p. 17

Vetter J (2003) Data on sodium content of common edible mushrooms. Food Chem 81:589-593

Vetter J (2005) Lithium content of some common edible wild-growing mushrooms. Food Chem 90:31-37

Vetter J, Hajdú J, Györfi J, Maszlavér P (2005) Mineral composition of the cultivated mushrooms Agaricus bisporus, Pleurotus ostreatus and Lentinula edodes. Acta Aliment 34:441-451

Yamanaka K (2011) Mushroom cultivation in Japan. World Soc Mushroom Biol Mushroom Prod Bull 4:1-10

Yujie C, Hongwei Y, Zhihui L (2007) Cultural characters and nutrition composition of Pleurotus djamor isolate H1. J Northeast For Univ 01:018

Zervakis GI, Venturella G, Papadopoulou K (2001) Genetic polymorphism and taxonomic infrastructure of the Pleurotus eryngii species-complex as determined by RAPD analysis, isozyme profiles and ecomorphological characters. Microbiology 147:3183-3194

Zhu F, Qu L, Fan W, Qiao M, Hao H, Wang X (2011) Assessment of heavy metals in some wild edible mushrooms collected from Yunnan Province, China. Environ Monit Assess 179:191-199 